\title{
Neoliberalism and the Paralysis of Human Rationality
}

Ian Raymond B. Pacquing

\begin{abstract}
The neoliberal character rests on the credo-"There is no alternative." There is no alternative to deregulation, free trade, individual entrepreneurship, and competition. This is believed by economists and intellectuals as the only way for humanity to be liberated from the feudal past. It is argued that this new economic liberalism reclaims the lost humanity of man. It is therefore through neoliberal perspectives that freedom and human creativity are realized. There is no other way but to engross oneself in this economic mainstream as transnational companies, through the help of IMF and the $\mathrm{WB}$, continuously occupy the social sphere. Economically, as individuals adapt to this capitalist mainstream, they assimilate their environment in accordance to the character matrix predominantly enforced by neoliberal apologists. Consequently, human potentialities are being absorbed into a system controlled by the very socio-economic apparatuses of modern society. Human reason becomes its very instrument as it is refashioned into a reified system of thinking. Human consciousness is captured in a single dimensional space propagated by this liberal economy. Individual growth, creativity, spontaneity, and productivity are all incorporated and hobbled in order to transmit the structures of neoliberal paradigm.
\end{abstract}

Keywords: Neoliberalism, autonomy, freedom, reification

7 he $16^{\text {th }}$ and $17^{\text {th }}$ century British thinking propagated by Thomas Hobbes, John Locke, and Adam Smith presented a kind of liberalism that celebrated the unique nature of being human. ${ }^{1}$ Their insightful

${ }^{1}$ Cf. John Locke, Two Treatises of Government, ed. by Peter Laslett (London: Cambridge University Press, 1988), 412. On a similar note, Adam Smith arguing for man's liberty alluded to respect of equals in the social hierarchy. He argues that this respect depends on men who possessed that fundamental right of freedom and liberty. Cf. Smith, Adam, Theory of Moral Sentiments, ed. by D.D. Raphael and A.L. Macfie, vol. I of The Glasgow Edition of the Works and Correspondence of Adam Smith (Indianapolis: Liberty Fund, 1982), 231. In On Sympathy, Smith

(C) 2016 lan Raymond B. Pacquing

http://www.kritike.org/journal/issue 18/pacquing june2016.pdf

ISSN 1908-7330

$(c c)$ BY-NC-ND 
discourses dealt with the inherent quality of human individuals, which centered on freedom and liberty. However, this type of philosophy was transformed into a kind of liberalism, which is grounded on the market economy. Liberalism then follows an economic model that behaved according to a peculiar kind of rationality, which we may refer to as the "capitalist" rationality. Such economic model is based on the assumption that a free market of various capitalist competitors maximizes consumers' satisfaction. ${ }^{2}$ This model purports to liberate human beings from the shackles of the feudal past. In fact, this was also the thought of Mises and Hayek who embraced neoliberal thinking ${ }^{3}$ Both of them argued that the meaning of human freedom is to engage the individual at the level of the economic mainstream. It is to allow human potentiality to grow and nourish as the individual immerses himself in the market economy. As a matter of fact, the famous economist Amartya Sen argues that freedom and liberty is nothing but the upliftment of human life through capitalist constructs. Though economic efficiency speaks about income and utility, human freedom would be nothing if the government does not focus on individual entitlement, capabilities, and rights. Even if these same economic theories deal with civil liberties without emphasizing economic security for the people, it becomes just a theory. ${ }_{4}$ Moreover, the onslaught of capitalist mentality compelled

reiterated the classical adage that men should not be used as a means towards an end. Whatever happens to one ought to be viewed in the light in which any other citizen would view us. Commentators on Smith would say that the surpluses as a result of his entrepreneurial prowess would rather benefit the rest of the community instead of being pocketed for material affluence. The surplus of the entrepreneur should rather enhance the growth of the community instead of enriching the entrepreneur himself. Cf. Smith, Theory of Moral Sentiments, 12-13. Further, the negative notion of freedom as the absence from regulatory arm of the government finds its expression in the thought of Thomas Hobbes who argued that individual liberty is the absence of any form of coercion, force, or control that would impede the active participation and cooperation of man in his society. Cf. Thomas Hobbes, The Leviathan, ed. by J.C.A Gaskin (New York: Oxford University Press, 1996), 139.

${ }^{2}$ Cf. Richard Peet, Unholy Trinity (Manila, Philippines: IBON Books, 2004), 3. Further, the work of Irving Kristol argues that in a capitalist economy, all individuals are endowed with the same political rights. However, as far as economic rights are concerned, the individual depends on economic factors that ultimately determine winners and losers in the market competition. This is the reason why some professional courses, according to Kristol, are paid better than others. Economically, the standard for success depends on what capitalist society projects and not what the individual wants. See Irving Kristol, "A Capitalist Conception of Justice," in Business Ethics, 3 ${ }^{\text {rd }}$ ed., ed. by W. Michael Hoffman and Robert E. Frederick (New York: McGraw Hills, Inc., 1995), 68

${ }^{3}$ Cf. F.A. Hayek, The Constitution of Liberty (Chicago: University of Chicago Press, 1978), 3. On the other hand, Von Mises argues that freedom means to involve one's autonomy and individuality into the market enterprise. Cf. Ludwig von Mises, Preface to Liberalism, trans. by Ralph Raico (California: Cobden Press, 1985), xvi.

${ }^{4}$ Cf. Amartya Sen, "Welfare, Preference, and Freedom" in Journal of Econometrics, 50 (1991), 18

(c) 2016 Ian Raymond B. Pacquing http://www.kritike.org/journal/issue 18/pacquing june2016.pdf ISSN 1908-7330 
Fukuyama to argue that ideological battles in the distant past have ended, and we have to accept that freedom and liberty, which is a fundamental faculty of the individual, must be enshrined within the realm of capitalism. In fact, Fukuyama says that the liberal market economy, which is the basis of capitalist enterprise, is the final arrangement of modernity. ${ }^{5}$

Since the early 1930s, liberalism has acquired a new dimension, which is now anchored on an economic liberal rationality. Modernity acquires a rational behavior, which centers on one axiom, i.e., freedom of the market means freedom for everybody to achieve the dream of fulfilling human individuality and autonomy. ${ }^{6}$ It emphasizes on this peculiar human quality, which allows every individual to pursue what is beneficial for his growth and survival. In this context then the free market assumes that the economic sphere is a conditio sine qua non for the fulfillment of human life. Traditional liberalism has been transformed into an inherent feature of a globalized market economy. At this outset, the capitalist strategy is to allow transnational companies to be incorporated into the global market. It is here that human freedom is redirected and takes its course towards global corporate governance. ${ }^{7}$ This so-called global corporate governance is a characteristic of $21^{\text {st }}$ century capitalism. Capitalism deals with the free enterprise where economic experts meet together to enforce, control, and regulate certain economic plans and programs by particular institutions that share a common ideology. ${ }^{8}$ This liberal economic paradigm is otherwise known as neoliberal economy. It is an ideology that tries to incorporate human modes of productions into one global economy. ${ }^{9}$ As such, the

\footnotetext{
${ }^{5}$ Cf. Francis Fukuyama, The End of History and the Last Man (New York: The Free Press, 1992), ix

${ }^{6}$ Cf. Peet, Unholy Trinity, 3 . The apologists of neoliberalism argue that the philosophy of Adam Smith is based on his view that human nature is actually striving for peace, and this is achieved through economics. The dream of a peaceful society embarks the role of economics as part of the moral dimension of humanity. It is through economic principles that human individuals facilitate the peaceful exchange among all of the goods necessary for life. See also Raquel Lazaro, "Adam Smith: Anthropology and Moral Philosophy," in Revista Empresa y Humanismo, 13:1 (2010), 145-184.

${ }^{7}$ Cf. John Madeley, A People's World (Manila: IBON Books, 2003), 112

${ }^{8} \mathrm{Cf}$. Peet, Unholy Trinity, 3 . This global governance is the result of what transpired in
} the Bretton Wood Agreement in 1944. It must be remembered that the world suffered from two world wars. It is the purpose of this agreement to avoid international conflicts to happen again. Anup Shah, "A Primer on Neoliberalism" in Global Issues (22 August 2010), $<\underline{\text { http://www.globalissues.org/article/39/a-primer-on-neoliberalism }>, 8 .}$

${ }_{9}^{9}$ Cf. Peet, Unholy Trinity, 3. Neoliberalism was conceived by Mises in the early 1930s. However, it was Hayek and Friedman who managed to bring it into fruition when the so-called Bretton Woods Agreement happened just after the end of WWII. The Agreement resulted in a global-based policy that would help war-torn countries to economically develop. Cf. Michel Beaud, Introduction to The History of Capitalism $m_{L}$ trans. by Tom Dickman and Anny Lefebvre (New York: Monthly Review Press, 2001), 214. Geuss describes ideology this way: "In addition

(C) 2016 lan Raymond B. Pacquing

http://www.kritike.org/journal/issue 18/pacquing june2016.pdf

ISSN 1908-7330

(cc) BY-NC-ND 
freedom and liberty of every individual follows this economic compass for growth and productivity. In fact, Mises says that the neoliberal agenda, which is based on individual liberty, must be put into action in order to achieve "free trade in a peaceful world of free nations."10 Modern capitalist thinking believes so much on the capacity of the individual as the architect of history and, thus, the agent of modernity. ${ }^{11}$ For neoliberals, freedom and the market become so inseparable that the realization of one depends on the other. Paul Treanor argues:

Liberals believe that the form of society should be the outcome of processes. These processes should be interactive and involve all members of society. The market is an example, probably the best example, of what liberals mean by process. Liberals are generally hostile to any 'interference with process.' Specifically, liberals claim that the distribution of wealth as a result of the market is, in itself, just. ${ }^{12}$

to such basic existential needs, human agents and groups have more mundane needs, wants, and interests which a given set of habits, beliefs, and attitudes, a given 'culture' can satisfy more or less adequately. Starting, then, from the wants, needs, interests, and the objective situation of a given human group, we can set ourselves in the task of determining what kind of socio-cultural system or what world-view would be most appropriate for that group, i.e., what 'ideology' ... is most likely to enable the members of the group to satisfy their wants and needs and further their interests." Cf. Raymond Geuss, The Idea of Critical Theory (New York: Cambridge University Press, 1981), 22

${ }^{10}$ Mises, Preface to Liberalism, xvi

${ }^{11}$ Erich Fromm, Fear of Freedom, (U.S: Farrar \& Rinehart, 1942), 26. Hereafter cited as

FF.

${ }^{12}$ Cf. Paul Treanor, "Neoliberalism: Origins, Theory, and Definition," in Document Index (Paul Treanor Archive), <http://web.inter.nl.net/users/Paul.Treanor/neoliberalism.htmll>.

The free will and liberty to enter into an agreement with one's fellows constitutes what he calls the political economy. Cf. Beaud, The History of Capitalism, 33.

On the other hand, some political and economic theorists distinguish political from economic liberalism. Political liberalism refers to the fundamental rights of the individual as he actively participates in the social process. On the other hand, economic liberalism refers to the active engagement of the individual in the market to uplift his material sustenance. It is progressively improving his material situation within the ambit of trade and commerce. However, the distinction of the two cannot be separated in reality. There are political decisions that affect the individual's economic life in the same way that we cannot talk of an economic right without taking into consideration the individual's political rights. Cf. Edwin van de Haar, Classical Liberalism and International Relations Theory (New York: Pelgrave MacMillan, 2009), 18. Further, the negative notion of freedom as the absence of the regulatory arm of the government finds its expression in the thought of Thomas Hobbes, who argued that individual liberty is the absence of any form of coercion, force, or control that would impede the active participation and cooperation of man in his society. Cf. Hobbes, The Leviathan 139. Fromm commented on this negative aspect of freedom. Modernity for Fromm has not achieved its goals for the intention is always geared towards freedom from which is the absence of coercion or control. However,

(C) 2016 Ian Raymond B. Pacquing

http://www.kritike.org/journal/issue 18/pacquing june2016.pdf

ISSN 1908-7330

(cc) BY-NC-ND 
Traditionally, liberalism could be construed as imbibing political, social, or even religious human expressions. However, with the Great Depression in 1939, the notion of liberalism was gradually altered to include the economic aspect of society. The very purpose was to jack up employment under the guise of freedom and liberty..$^{13}$ Furthermore, freedom and liberty serve as the cornerstone of uplifting the material aspect of human life. It is in this context that this economic liberalism prioritizes modes of production as sources for improving the material welfare of society. It champions the entrepreneurial individual and the organizational efficiency of the market. ${ }^{14}$

Because of the structures of this economic liberalism, ${ }^{15}$ Margaret Thatcher strongly believed that there is no such thing as society, and everything must be reduced to and for the individual, private property, personal responsibility, and family values. ${ }^{16}$ It is only the individual with all the capacities rooted in him that matters in neoliberal paradigm. Consequently, the market economy, which anchors its beliefs on 'ideals,' becomes exemplary, says Žižek, since the market enterprise considers human nature to be egotistic. ${ }^{17}$ It is egotistic in a sense that the individual may create and produce anything under the domain of neoliberal agenda. Nothing

Fromm asserts that freedom also entails the freedom to, i.e., the freedom to march towards the vision of the human race. Cf. Fromm, $F F$, 33-38.

${ }^{13}$ Cf. Elizabeth Martinez and Arnaldo Garcia "What is Neoliberalism: A Brief Definition for Activist," in CorpWatch, <http://www.corpwatch.org/article.php?id=376 $>$. Moreover, economic liberalism was enshrined by intellectuals, says Foucault, because the state was in need of "the requirement of reconstruction, that is to say, the conversion of a war economy back into a peace economy, the reconstruction of destroyed economic potential ... of new technological information which appeared during the war, and new demographic and geopolitical facts." Cf. Michel Foucault, The Birth of Biopolitics: Lectures at College de France 19781979, ed. by Michel Senellart, trans. by Graham Burchell (New York: Pelgrave Macmillan, 2008), 79.

${ }^{14}$ Cf. Peet, Unholy Trinity, 4.

${ }^{15}$ Harvey described this nature of neoliberal paradigm as embedded economic liberalism. As such, it becomes a strategy for economic and industrial proficiency. Cf. David Harvey, A Brief History of Neoliberalism (New York: Oxford University Press, 2005), 11

${ }^{16} \mathrm{Cf}$. Ibid., 23. However if we look at the motives behind the implementation of neoliberal agenda under the guise of human freedom and liberty, there is a collusion between government and corporations to engage themselves in amassing profit at the expense of liberty and individuality. In other words, there is a deceit that is hidden behind every good intention in the neoliberal dream. Birch and Mykhnenko commented that, "The very idea that markets are self-organizing, efficient, and liberating is no longer credible, but illustrates the extent to which neoliberalism - as shorthand for market-like rule-is an economic, political, and ideological project pursued by certain groups (such as governments and corporations) to construct a reality that is perceived to be founded in the inherent properties of economic markets." Kean Birch and Vlad Mykhnenko, "Introduction: A World Turned Right Way Up," in The Rise and Fall of Neoliberalism: The Collapse of an Economic Order, ed. by Kean Birch and Vlad Mykhnenko (New York: Zed Books, 2010), 2.

${ }^{17}$ Cf. Slavoj Žižek, Living in the End Times (London: Verso, 2010), 36.

(C) 2016 lan Raymond B. Pacquing

http://www.kritike.org/journal/issue 18/pacquing june2016.pdf

ISSN 1908-7330

(cc) BY-NC-ND 
prevents the individual from expressing his humanity as long as it is done within the market enterprise. ${ }^{18}$ Further, as the individual becomes the epitome of this market ideology, more are craving for and claiming governmental protection of their rights disguised under the name of freedom and liberty. However, as Perelman argued, though the individual is protected by the government, his rights must be subsumed into trade and commerce as sources of power and social mobility. ${ }^{19}$ As a matter of fact, even Erich Fromm recognizes the fact that through the capital, the individual sees himself as the subject and agent of social mobility. ${ }^{20}$ The capital is seen as one among the necessary factors for individualizing freedom and liberty. Through the capital, neoliberal agenda moves towards the empowerment of the individual through economic growth and welfare. As Stanley Fischer, Deputy Managing Director of the International Monetary Fund, argues: "free capital movements facilitate a more efficient global allocation of saving and helping channel resources into their most productive uses, thus, increasing economic growth and welfare." 21 In fact, the noted economist Joseph Stiglitz observes that in order to achieve economic growth and welfare, the global market should be free from any governmental control, and to realize this, the only role given to the state is to enforce policies and contracts, which are beneficial to the market. 22

The Bretton Wood Agreement of 1944 signals the conception of neoliberal thinking. This agreement among nations became crucial in realizing the vision of neoliberal philosophy. It has to be noted that the brutal and relentless expansion of Europe and America ceded when 44 nations agreed to institutionalize the market economy. ${ }^{23}$ In order to maintain peace, equality, and regional stability, the agreement wanted to restore the structures of capitalism and at this time, it must be done with a 'human face.' However, it was in the early 1980 that neoliberal structures came into full force declaring that There is No Alternative (TINA) to this economic system

${ }^{18}$ Hayek argues that the "object of most Western thinkers has been to establish a society in which every individual, with a minimum dependence on discretionary authority of his rulers, would enjoy the privileges and responsibility of determining his own conduct within a previously defined framework of rights and duties." Cf. Hayek, The Constitution of Liberty, 3.

${ }^{19}$ Michael Perelman, The Invention of Capitalism (London: Duke University Press, 2000), 15.

${ }^{20}$ Cf. Fromm, FF, 38

${ }^{21}$ Cf. Kavaljit Singh, Questioning Globalization (Manila: IBON Books, 2004), 18.

${ }^{22}$ Cf. Joseph Stiglitz, Globalization and Its Discontents (New York: Allen Lane/ Penguin Books, 2002), 74

${ }^{23}$ Joyce Appleby, A Relentless Revolution: History of Capitalism (New York: W.W. Norton \& Company, 2010), 165.

(c) 2016 Ian Raymond B. Pacquing http://www.kritike.org/journal/issue 18/pacquing june2016.pdf ISSN 1908-7330 
that modernity has to offer. ${ }^{24}$ Everything falls under the name of freedom and liberty. Although the market is the 'venue,' neoliberal thinking adheres to freedom as the fundamental political value. ${ }^{25}$ Leys asserts that the purpose of this economic restructuring is something material, i.e., "radical transformation in both the structure and the management of the world economy ... creating for the first time in history a truly unified global capitalist economy ... reflecting the interests of transnational capital." 26

Nevertheless, considering these modern economic structures, I maintain that with this ideology of neoliberalism, ${ }^{27}$ humanity is pushed further towards abstrafication and quantification of its potential. The human regression towards reification is brought about by the fortification of the internal structures of the economic policies of neoliberal ideology. Its homogenizing and hegemonizing factors, psychoanalytically speaking, dislodge human rationality because its historical reference is transformed into a reified discursive system of thinking. It is implicitly expressing that the only measure to live freely and humanely is to engage oneself in the market enterprise. Hence, human thoughts, actions, and feelings are swayed and instrumentalized into this economic paradigm. In fact, the psychologization of humanity through the embedded neoliberal economy "has reduced human beings to fungible, commensurable values, expunging what makes them particular or unique." 28 It attracts individual psychic energies to imbibe an economy which is thought of as liberating and thus humanizing. It builds a character where humans are cajoled into believing that they will all the more be free. Human freedom is actualized when one allows oneself to engage in the market economy. Hence, a person allures himself in the exchange of commodities that takes place within the market sphere. With digital

${ }^{24}$ Cf. Jason Hickel, "A Short History of Neoliberalism (And How We Can Fix It)" in New Left Project (09 April 2012), <http://www.newleftproject.org/index.php/site/ article comments/a short history of neoliberalism and how we can fix it $>, 1$.

${ }^{25}$ Jodi Dean, Democracy and Other Neoliberal Fantasies (U.S.: Duke University Press, 2009), 51.

${ }^{26}$ Collin Leys, "The Rise and Fall of Development Theory," in The Anthropology of Development and Globalization, ed. by Marc Edelman and Angelique Haugerud (U.S.: Blackwell Publishing, 2005), 114.

${ }^{27}$ Neoliberal ideology is actually a reversion to the old capitalistic thinking advocated by Adam Smith. In the works of Harvey, Hardt, and Negri, they argued that neoliberalism is actually a continuation of Smith's capitalist enunciation of economic life. However, this neoliberal concept was extended into a globalized economy where participant nations should abide by the rules and policies of a global corporate structure, which in return is protected by the laws and policies of the state. Cf. Harvey, A Brief History of Neoliberalism, 5-10. This collusion between the state and corporation forms what is called corporate empire where the economic, social, political, and cultural aspects of life overlap. Cf. Michael Hardt and Antonio Negri, Empire (London: Harvard University Press, 2000), xiii.

${ }^{28}$ Deborah Cook, Adorno, Habermas, and the Search for A Rational Society (London: Routledge, 2004), 11.

(C) 2016 lan Raymond B. Pacquing

http://www.kritike.org/journal/issue 18/pacquing june2016.pdf

ISSN 1908-7330

(c) $)$ BY-NC-ND 
technology within everybody's reach, every individual becomes the master of himself. Anybody who criticizes this way of living is not 'identical' to the normative apparatus of neoliberalism. In fact, its mythological aspect would denounce any critical stance that would conceal its exploitative and dominative agenda. Further, with the neoliberal thinking, and although freedom and liberty serve as the core of this economic system, human individuality is annihilated and reified by the production of commodities. ${ }^{29}$ While it is a fact that modernity moves towards human freedom from the old feudal system and a renewal of human individuality and independence, the neoliberal paradigm has unconsciously restrained human beings, engendering fear, anxiety, and compulsion. ${ }^{30}$ We experience ourselves as

${ }^{29}$ Cf. Georg Lukacs "History and Class Consciousness, 1920," in History and Class Consciousness, ed. by Andy Blunden, trans. by Rodney Livingstone (London: Merlin Press, 1967), 12.

${ }^{30}$ According to Chomsky, the dialectic between these industrial corporations and the U.S. "activist" foreign policies fortify and extend U.S. power through subversion, international terrorism, and aggression. This dialectic is a way to 'Americanize' human life. Cf. Noam Chomsky, Necessary Illusions: Thought Control in Democratic Societies (London: Pluto Press, 1989), 12. As far as the political situation is concerned, Martha Sieburth also observes, "This first decade of the 21st century, we have experienced instead extremely unstable global situations, with terrorism since September 11, 2001, becoming even more widespread. Train bombs exploded in Madrid on March 11, 2004, and in London in 2005. In September 2008, the ETA Basque separatist movement resumed bombings after having signed a peace ceasefire in 2006. The wars in Iraq and the incursion of Taliban fighters in Afghanistan have dramatically weakened the U.S. economy, and the continued saga between Israelis and Palestinians in the Middle East ... violence has become an accepted way of life and global destabilization is becoming more and more "normalized." Martha Seiburg, Foreword to Revolutionizing Pedagogy: Education for Social Justice Within and Beyond Global Neo-liberalism, ed. by Sheila Macrine, Peter McLaren, and Dave Hill (New York: Palgrave Macmillan, 2010), x. According to Stiglitz, the principles of neoliberal politics needed to be rethought because they cater no longer to the less developed people of the world but to the interest of those people who are in power. See Joseph Stiglitz, Preface to Globalization and Its Discontents, (New York: Allen Lane/Penguin Books, 2002), ix-xii. The fact that the 'Uruguay Round' in 1995 collapsed because of the imbalanced distribution of goods and services especially in agricultural products to developing countries, which now indicate that the ruling elite, which belongs to U.S.-based transnational companies, gets the better share. (For further discussion why U.S. and EU had unresolved trade conflicts and needed to come up with a resolution in terms of agricultural products, see "Understanding the WTO," in World Trade Organization, $<$ http://www.wto.org/english/thewto e/whatis e/tif e/agrm1 e.htm $>$.) The effects of these economic inequalities are best described in the riot in Genoa, which led to bloodshed. See Cf. David Schweickart, After Capitalism (US: Rowman \& Littlefield Publishers, Inc., 2002), 6. Further, Schweickart adds, "In the face of massive and violent police retaliation, they shut down the World Trade Organization's (WTO) opening ceremony, prevented President Clinton from addressing the WTO delegates, and compelled the WTO to cancel its closing ceremonies and adjourn in disorder and confusion. Since then, protests, self-consciously linked to the Seattle upheaval and to each other, have erupted in Quito, Ecuador (January 2000), Washington, D.C. (April 2000), Bangkok (May 2000), South Africa (May 2000), Buenos Aires (May 2000), Windsor/Detroit and Calgary June 2000), Millau, France (June 2000), Okinawa (July 2000), Colombia (August 2000), Melbourne (September 2000), Prague (September 2000), Seoul (October 2000), Davos, Switzerland (January 2001), Quebec City (April 2001), and most recently (as of this

(C) 2016 Ian Raymond B. Pacquing

http://www.kritike.org/journal/issue 18/pacquing june2016.pdf

ISSN 1908-7330

(c) BY-NC-ND 


\title{
154 NEOLIBERALISM
}

\author{
inhabited and driven by forces that are mysterious to us. These mysterious \\ forces include economic forces that structure our lives as beings who must
}

writing - there will have been others by the time you read this) Genoa (July 2001). [Post September 11 update: A sizable contingent of protestors trekked to far-off Qatar in November 2001, where nervous WTO ministers decided to hold their post-Seattle meeting, while tens of thousands more rallied in their own countries - some thirty countries in all-to analyze and criticize the WTO agenda. In New York City in February 2002, some fifteen thousand rallied against the World Economic Forum being held there, while thousands more went to Porto Alegre, Brazil, for a "World Social Forum," which billed itself as a counter-WEE. Despite media pronouncements to the contrary and despite the fact that governments are using the "threat of terrorism" to make protest more difficult, the events of September 11 have not derailed this "movement for global justice." In the Philippines, when the Ramos-Macapagal regimes, through Roberto de Ocampo as Secretary of Finance and NEDA Chief Cielito Habito, made the country a party to the ASEAN Free Trade Area and eventually joined the World Trade Organization in 1995, domestic casualties occurred. Bello says, "The list of industrial casualties included paper products, textiles, ceramics, rubber products, furniture and fixtures, petrochemicals, beverage, wood, shoes, petroleum oils, clothing accessories, and leather goods. By the early years of this decade, the country's textile industry had shrunk from 200 to less than 10 firms." See Walden Bello, "Neoliberalism as Hegemonic Ideology in the Philippines: Rise, Apogee, and Crisis" (Plenary Paper presented at the National Conference of the Philippine Sociological Society, Philippine Social Science Center (PSSC) Building, Quezon City, Metro Manila, 16 October 2009. See also Walden Bello, "Neoliberalism as Hegemonic Ideology in the Philippines: Rise, Apogee, and Crisis," in Focus on the Global South, <http://focusweb.org/node/1534>, 3. Although neoliberalism has globalized the world, there are other vital dimensions: global climate change, the decay of the ozone layer, and the pollution of the oceans all bring the world's people closer together, if only because decisions made in one place shape other places. The result is an odd and novel situation. See Geoff Mulgan, "The Age of Connexity," A Globalizing World? Culture, Economics, Politics, $2^{\text {nd }}$ ed., ed. by David Held (London: Routledge, 2004), 11. If one does not conform to the demands of neoliberal thinking, political and cultural consequences follow. Perkins says, in addition to this, the effects of this imperial status drip to those countries which have been promised infrastructures, health, education, and military partnership. As a superpower and through WTO, IMF, and WB, the U.S. offers loans to developing countries. These loans are given to help infrastructure projects, which developing countries cannot financially sustain. Foreign contractors and engineers go and help build airports, highways, parks, electric plants, etc. What these developing countries do not know is that the loans are pegged in the U.S. dollar. It is then coursed through different U.S transnational companies, which help build these infrastructure projects. In other words, U.S. promises aids through these transnational companies. Consequently, the amount of dollars that leaves the U.S. treasury reverts to them immediately through these mighty corporations. Moreover, the loans that come through foreign aids are now being paid with collateral and interest. Now, this is the rub-U.S. knows very well that these countries cannot pay and thus declared to default on their payments. The longer they cannot pay, the better since the interests grow. This economic and political strategy in the international scene is a deception in order to build an empire. As more and more countries are ensnared in debt, the more they become loyal to the U.S. economic hegemony. Thus, U.S. democratic terms expand as a matter of its political sovereignty. Those countries, which cannot pay their debts, are obliged to kowtow to the dictates of U.S. hegemony. Hence, they have to open their natural resources for U.S. control, their votes in the U.N. are stricken over in favor of the U.S., and U.S. military base are installed - these are just among the many consequences of this loyalty. Cf. John Perkins, Prologue to The Confessions of an Economic Hit Man, (California: Berrett-Koehler Publishers, Inc, 2004), xiii,

(C) 2016 lan Raymond B. Pacquing

http://www.kritike.org/journal/issue 18/pacquing june2016.pdf

ISSN 1908-7330

(cc) BY-NC-ND 
sell labor power to others. ${ }^{31}$ Consequently, this ideology entails a twisted notion of freedom characterized by the accentuation and internalization of dependency, as opposed to integrity and autonomy. ${ }^{32}$ The engagement of modernity in these economic structures involves a mouse trap where humanity acquires freedom from the old structures yet caged in a new system where human individuality is lost. ${ }^{33}$ As it was pointed out by Mark Blyth, neoliberal thinking with its own material monetary base as developed by Friedman ${ }^{34}$ isolates human nature from its real vocation: activity and productivity. ${ }^{35}$

In this context, I agree with what Marx said in his The Economic and Philosophical Manuscripts of 1844, ${ }^{36}$ and later on developed by Fromm in his Beyond the Chain of Illusion ${ }^{37}$ - that human consciousness is affected by the internal logic of the material base of society. According to Fromm, while human beings emancipated themselves from the shackles of the past, their

${ }^{31}$ Cf. Ian Parker, Revolution in Psychology: Alienation to Emancipation (London: Pluto Press, 2007), 5.

32 Cf. Fromm, FF, 92. One can also see this argument in the book review of Frank Knight. See Frank H. Knight, Review of Erich Fromm, Escape from Freedom, in American Journal of Sociology, 48:2 (1942), 299.

${ }^{33}$ Fromm argues that although industrial capitalism was a freedom from, it does not answer the freedom to. Cf. Fromm, FF, 33. On the same breadth, Schmidtz and Brennan argue that although freedom, from its classical connotation, would always entail freedom from, what liberals have forgotten is the freedom to. Cf. David Schmidtz and Jason Brennan, A Brief History of Liberty (London: Wiley and Blackwell, 2010), 7

${ }^{34}$ Cf. Peet, Unholy Trinity, 4

${ }^{35}$ Cf. Erich Fromm, The Art of Loving (London: George Allen and Unwin Publishers, 1957), 7. Hereafter cited as AOL.

${ }^{36}$ Marx says, "Capital is, therefore, the power to command labor, and its products. The capitalist possesses this power not on account of his personal or human properties but insofar as he is an owner of capital. His power is the purchasing power of his capital, which nothing can withstand." Cf. Karl Marx, The Economic and Philosophical Manuscripts, trans. by Gregor Benton, transcribed by Andy Blunden, in Marxist Internet Archive (1993), < https://www.marxists.org/archive/marx/works/1844/epm/1st.htm\#s2>, 17. Further Marx laments that the industrial or neoliberal construct pushes the worker into such condition, i.e., the working class who is made to subordinate himself to the capitalist. The more capital is invested, the more amount of labor is extracted from the worker. Consequently, the more he has to sacrifice his time and freedom and work as a slave. Cf. Marx, The Economic and Philosophical Manuscripts, 7. On the contrary, the more capital means there are, the more labor is imputed, and the more workers there are, the more division of labor is demanded. For Marx, it is only the capitalist who is at a better advantage in this kind of situation. Under these existing working conditions, remunerations and benefits do not remove the fact that structures of capitalism make the worker regress to inhuman situations. Psychologically, Fromm says, "increase in wages does not restore their lost human significance and worth." Cf. Erich Fromm, Marx's Concept of Man (London: Continuum, 1961), 34.

${ }^{37}$ It is not only in the Beyond the Chain of Illusion: My Encounter with Marx and Freud (1962); we can also read the arguments of Fromm from his other monumental works like Fear of Freedom (1941), Sane Society (1956), Man for Himself: An Inquiry into the Psychology of Ethics (1947), Art of Loving (1956), and Revolution of Hope (1968).

(c) 2016 Ian Raymond B. Pacquing http://www.kritike.org/journal/issue 18/pacquing june2016.pdf ISSN 1908-7330 
lives have, however, become more quantitative and, as such, individuality and autonomy are undermined. While the cornerstone of capitalist agenda was the promise of freedom, this is challenged by how the capitalist mind frame has taken over human lives. Humanity is now threatened by the vast monopoly and superior strength of capital and, thus, the more an individual becomes isolated and aggravated..$^{38}$ The very faculties which are supposed to deliver humanity towards a better society have been reified by the very characterology of modernity. How the material productions of society are restructured to achieve a common end affects how human beings view themselves, others, and their world. It must be noted that the dialectic between the substructure and the superstructure of which the modern individual is a part psychologically sways human energy to follow the inner logic enunciated by neoliberalism. As individuals recreate society, their creativity manifests itself in their own human productivity. However, through their own production and creativity, the effects of neoliberal thinking commercialize everyday life so that human and individual relationships "interact with a lifeless object without a trace of inner sentiment or any attempt at understanding the other's point of view." 39 Individuality has become instrumentalized at the service of this economic paradigm. The conscious elements of human adaptation and assimilation to his or her immediate environment have yielded to the commodification of life. The

38 The neurotic symptoms of contradictory strivings from what Freud called sexual libido and the need for human survival positioned Fromm to call modern society as the pathos of normalcy. The conflict between human necessities arising from acts of survival and necessities arising from the postponement of pleasure lead humanity to insanity for the reason that "all behave irrationally in this irrational world." In his study of modern capitalism, Fromm found out that the economic modes of productions would force us to behave irrationally and thus neurotically. This neurotic behavior leads humanity towards the formation of automatonbeings which are abstracted and quantified by forces of the modern industrial capitalism. Cf. Erich Fromm, "Method and Function of an Analytic Social Psychology," in The Essential Frankfurt School Reader, ed. by Andrew Arato and Eike Gebhardt (New York: Continuum Publishing Company, 2002), 477. This comment is also seen in Fromm's Crisis of Psychoanalysis (1970). See Erich Fromm, "Crisis of Psychoanalysis: Essays on Freud, Marx, and Social Psychology," in Critical Theory and Society: A Reader, ed. by Stephen Bronner and Douglas Kellner (London: Routledge, 1989), 247.

${ }^{39}$ Axel Honneth, Reification: A New Look at an Old Idea, ed. by Martin Jay (New York: Oxford University Press, 2008), 18. However, Honneth argues that an objective understanding of person and of the world is possible without gearing towards reification. Objectification is a prerequisite in an emphatic engagement of the individual with the world for there is already, in the process of assimilation, an antecedent act of recognition between the infant and his surrounding world. For Honneth, the antecedent recognition is an objectification process without falling within the realm of reification. Honneth comments, "If everything within a society is reified just because it urges the adoption of an objectifying attitude, then human sociality must have vanished complete." Thus, Honneth would redefine reification as an amnesia which forces us the ability to understand the behavioral expression of others as making demands of us. Cf. Honneth, Reification, 50-70.

(C) 2016 lan Raymond B. Pacquing

http://www.kritike.org/journal/issue 18/pacquing june2016.pdf

ISSN 1908-7330

(c) $)$ BY-NC-ND 
moral and ethical aspects of human relationships are objectified and commodified. ${ }^{40}$ In the observation of Chomsky, the systematic use of capitalist propaganda in order to alter and regiment the consciousness of the people is a mark of the neoliberal agenda. ${ }^{41}$ Further, while these assimilation and adaptation are products of the individual conscious actions, there lies in the unconscious libidinal structure of society hidden motivations which are enunciated by neoliberal thinking. Though the objects that modernity produce do affect human consciousness, we cannot disregard the fact that the world that the consciousness perceives is a world that has already been changed by a 'capitalist' consciousness. The dialectic between the material modes of productions and the productive and creative faculty of human individuals cannot be discounted. As Wiggerhaus argues, "What connections there are between the social development of humanity, particularly its economic and technical development and the development of its mental faculty, particularly the ego-organization of the human being?" 42 It is for these reasons that I contend, following Frommian philosophy, ${ }^{43}$ that the socioeconomic foundations of modernity accentuate a particular characterology that redirects the social psychic apparatuses towards dependency, submission, conformity, and paralysis of human rationality. ${ }^{44}$ The structures

\footnotetext{
${ }^{40}$ Cf. Ibid., 19.

${ }^{41}$ Cf. Noam Chomsky, Profit Over the People: Neoliberalism and the Global Order (New York: Seven Stories Press, 1999), 53.

${ }^{42}$ Rolf Wiggerhaus, The Frankfurt School: Its History, Theories, and Political Significance, trans. by Michael Robertson (Cambridge: MIT Press, 1995), 5 .

${ }^{43}$ Introduced by Lowenthal, Erich Fromm became the most prominent figure as he headed the division of social psychology of the Institute from 1934 up to 1939. It was through him that the Institute first attempted to fuse the psychoanalysis of Freud and the social philosophy of Marx. Cf. Martin Jay, The Dialectical Imagination (London: Heinemann Educational Books, Ltd., 1973), 88. According to Kellner, Fromm was trained in sociology and psychoanalysis and was able to develop a Marxian social psychology. Cf. Douglas Kellner, "Erich Fromm, Judaism, and the Frankfurt School," in Illuminations: The Critical Theory Project, $<$ https://pages.gseis.ucla.edu/faculty/kellner/lllumina\%20Folder/kell24.htm $>$. It is through his training that he was hired by Horkheimer as the psychologist of the Institute for Social Research. Horkheimer saw the need to have a critical social psychology and this was to fuse the works of Marx and Freud. Cf. Stephen Bronner and Douglas Kellner, Introduction to Critical Theory and Society: A Reader (London: Routledge, 1989), 4; Cf. Wiggerhaus, The Frankfurt School, 51. The Frommian psycho-social philosophy speaks of determining the false ideologies that sway human energies towards the pathologies of society. Further, Kellner says that in the mixture of Marx and Freud, Fromm rejects any transcendental dimension of life and believes that intellectual responses to life are derivative of material needs and social experiences. Cf. Kellner, "Erich Fromm, Feminism, and the Frankfurt School: Reflection on Patricial Mills' Woman, Nature, and Psyche," in Illuminations: The Critical Theory Project,
} $<$ https://pages.gseis.ucla.edu/faculty/kellner/Illumina\%20Folder/kell27.htm>.

${ }^{44}$ Fromm says, "We are concerned with instrumentalities - with how we are doing things; we are no longer concerned with why we are doing things. We build machines that act like men and we want to produce men who act like machines." Erich Fromm, "Freedom in the

(c) 2016 Ian Raymond B. Pacquing http://www.kritike.org/journal/issue 18/pacquing june2016.pdf ISSN 1908-7330 
of neoliberalism attract individual impulses to acquire a dependent character of which modernity is unconscious. ${ }^{45}$ As a matter of fact, the individual conscious action speaks of the great humanist values, such as love, freedom, and equality; however, unconsciously, one is motivated to act in accordance with the conditions of those material forces articulated by neoliberal philosophy. There is then a contradiction between the humanistic desire that gears towards human growth and the socio-economic foundation from which the survival of society rests. As Lawrence Freidman observes, neoliberal thinking has "paralyzed human rationality to the point where the pride in a common humanity had subsided." 46

The inner logic of the material forces of society becomes, what Fromm calls, the "bedrock of man's social character." A social character leads to particular behavioral traits of society. The interaction between the social character and the collective unconscious results in how human beings think and act to achieve the goals which society aspires. The psychic energy of society is redirected to follow the social economic pattern, and in return, human consciousness becomes hobbled and reified. Human reason, which could have led modernity towards human potentials, is paralyzed as a result of a characterology built within the ambit of neoliberal philosophy. ${ }^{47}$ The

\footnotetext{
Work Situation," in Arbeit - Entfremdung - Charakter, vol. 3 of The Yearbook of the International Erich Fromm Society (Münster: LIT Verlag, 1994).

${ }^{45} \mathrm{In}$ fact, many commentators like Giddens argue that the neoliberal construct is the 'Americanization' of human life to the extent that transnational companies that come to dominate the socio-cultural lifeworld of individual localities are based in the U.S. and in the North. We take for instance McDonalds and Coca-Cola dominating the local mainstream. This would show that it is really an affair of the North where the South doesn't have any active role. That is why Giddens argues that globalization (neoliberalism) "would see it as destroying local cultures, widening world inequalities, and worsening the lot of the impoverished. Globalisation, some argue, creates a world of winners and losers, a few on the fast track to prosperity, the majority condemned to a life of misery and despair ..." Anthony Giddens, "Lecture 1," in Runaway World (London: Profile Books, 1999), as cited in Allan Cochrane and Kathy Pain, "A Globalizing Society," in A Globalizing World? Culture, Economics, Politics, ed. by David Held (London: Routledge, 2004), 12.

${ }^{46}$ Lawrence Friedman, The Lives of Erich Fromm: Love's Prophet (New York: Columbia University Press, 2013), 228.

${ }^{47}$ One needs to know that global finance, for instance, is regulated and controlled by the International Monetary Fund and the World Bank. It is in these two institutions that the financial infrastructures of the global market are coursed through. On the other hand, the United Nation's assistance to developing and war-torn countries like Iraq and Israel must be aligned with the policies of these two institutions. However, the fortifications of these lie in the modes of communication that we have. Considering that global telecommunication companies like Google and Microsoft are based in the U.S., the power to regulate and control world economy, politics, and culture is still dependent on the dictates of the sole superpower of the world, i.e., the U.S. This is the reason why each locality, or even regional city, is at the mercy of these powerful institutions, which have powerful structural effects severely affecting the sovereignty of nation states. See Cochrane and Pain, "A Globalizing Society," in A Globalizing World, 17.
}

(c) 2016 lan Raymond B. Pacquing

http://www.kritike.org/journal/issue 18/pacquing june2016.pdf

ISSN 1908-7330

(cc) BY-NC-ND 
ideology of neoliberalism is a product of an economic psychologization to the extent that the oppression and exploitation in the world are camouflaged by 'images and appearances,' which seem so natural and normal for an ordinary individual. ${ }^{48}$ I contend, therefore, that if we fail to understand both social character and social unconscious, it is impossible to know and understand social pathologies, which continuously affect human lives. Ignoring the social character and the social unconscious, social pathologies are just considered as the normal flow of social and human transactions. Social pathologies ${ }^{49}$ would just be transformed into social 'common sense' in which case humanity acquires an irreversible pattern that leads to death and decay..$^{50}$

Department of Philosophy, University of Santo Tomas, Philippines

\section{References}

Appleby, Joyce, A Relentless Revolution: History of Capitalism (New York: W.W. Norton \& Company, 2010)

Arato, Andrew, and Eike Gerhardt, The Essential Frankfurt School (New York: Continuum Publishing Company, 2002),

Beaud, Michael, Introduction to The History of Capitalism, trans. Tom Dickman and Anny Lefebvre (New York: Monthly Review Press, 2001)

Birch, Kean and Vlad Mykhnenko, The Rise and Fall of Neoliberalism: The Collapse of an Economic Order (New York: Zed Books, 2010)

48 Cf. Parker, Revolution in Psychology, 48. It is in this process of 'images and appearances' that an individual relates, transcends, and becomes rooted on images and appearances. It is a character of 21st century man to repeat these 'images and appearances' as a matter of reasoned arguments and carefully analyzed opinions until they are converted into common sense. Consciously, the individual thinks, reasons, and argues as a matter of human discourse. But with the internalized ideology, he is just replicating the falsity of this ideology. He cannot see the contradictions that lie within because his personality is a reflection of that very ideology that categorized him. The social characterology of this economic system has removed his "I" as a form of self-identity. Fromm lamented this fact and he foretold decades ago that the fate of the 21st century has already been sealed. If man cannot see the illusions or ideologies that muster and control his energy, then he is doomed towards perdition. Cf. Fromm, Revolution of Hope, 27.

${ }^{49}$ Social pathology is the description used by Fromm to imply the illusions brought about by an irrational social characterology as it reifies and hobbles the consciousness. Cf. Fromm, Sane Society, 60-80. In his Revolution of Hope, he narrates how the social character of the $20^{\text {th }}$ century capitalism 'commodifies' reason as an instrumentality of the modes of production in order to perpetuate its legitimacy in the modern world. Cf. Fromm, Revolution of Hope, 55.

50 William Martin Kennedy, Implications for Counselling from Erich Fromm's View of Man's Ethical Responsibility (Ph.D. Dissertation, Austin: University of Texas/ Erich Fromm Document Center), 147.

(C) 2016 lan Raymond B. Pacquing

http://www.kritike.org/journal/issue 18/pacquing june2016.pdf

ISSN 1908-7330 
Bello, Walden, "Neoliberalism as Hegemonic Ideology in the Philippines: Rise, Apogee, and Crisis," in Focus on the Global South, $<$ http://focusweb.org/node/1534>.

Bronner, Stephen, and Douglas Kellner, Critical Theory and Society: A Reader (London: Routledge, 1989).

Chomsky, Noam, Necessary Illusions: Thought Control in Democratic Societies (London: Pluto Press, 1989).

Profit Over the People: Neoliberalism and the Global Order (New York: Seven Stories Press, 1999).

Cook, Deborah, Adorno, Habermas, and the Search for A Rational Society (London: Routledge, 2004).

Dean, Jodie, Democracy and Other Neoliberal Fantasies (U.S.: Duke University Press, 2009).

Foucault, Michelle, The Birth of Biopolitics: Lectures at College de France 19781979, ed. by Michel Senellart, trans. by Graham Burchell (New York: Pelgrave Macmillan, 2008).

Erich Fromm, Fear of Freedom (U.S: Farrar \& Rinehart, 1942). "Freedom in the Work Situation," in Arbeit - Entfremdung -

Charakter, vol. 3 of The Yearbook of the International Erich Fromm Society (Münster: LIT Verlag, 1994). 1957). The Art of Loving, (London: George Allen and Unwin Publishers, The Revolution of Hope (New York: Rinehart and Holt, 1970).

Fukuyama, Francis, The End of History and the Last Man (New York: The Free Press, 1992).

Geuss, Raymond, The Idea of Critical Theory (New York: Cambridge University Press, 1981).

van de Haar, Edwin, Classical Liberalism and International Relations Theory: Hume, Smith, Mises, and Hayek (New York: Palgrave MacMillan, 2009).

Hardt, Michael, and Antonio Negri, Empire (London: Harvard University Press, 2000).

Harvey, David, Brief History of Neoliberalism (New York: Oxford University Press, 2005).

Hayek, F.A., The Constitution of Liberty (Chicago: University of Chicago Press, 1978)

Held, David, ed., A Globalizing World? Culture, Economics, Politics, $2^{\text {nd }}$ ed. (London: Routledge, 2004).

Hickel, Jason, "A Short History of Neoliberalism (And How We Can Fix It)" in New Left Project (9 April 2012) $<$ http://www.newleftproject.org/index.php/site/article comments/a short history of neoliberalism and how we can fix it $>$. 
Hobbes, Thomas, The Leviathan, ed. by J.C.A. Gaskin (New York: Oxford University Press, 1996).

Honneth, Axel, Reification: A New Look at an Old Idea, edited and introduced by Martin Jay (New York: Oxford University Press, 2008).

Kristol, Irving, "A Capitalist Conception of Justice," in Business Ethics, $3^{\text {rd }}$ ed., ed. by W. Michael Hoffman and Robert E. Frederick (New York: McGraw Hills, Inc., 1995)

Lazaro, Raquel, "Adam Smith: Anthropology and Moral Philosophy," in Revista Empresa y Humanismo, 13:1 (2010).

Leys, Collin, "The Rise and Fall of Development Theory," in The Anthropology of Development and Globalization, ed. by Marc Edelman and Angelique Haugerud (U.S.: Blackwell Publishing, 2005)

Locke, John, Two Treatises of Government, ed. by Peter Laslett (London: Cambridge University Press, 1988)

Lukacs, Georg, "History and Class Consciousness, 1920," in History and Class Consciousness, ed. by Andy Blunden, trans. by Rodney Livingstone (London: Merlin Press, 1967).

Macrine, Shiela, Peter McLaren, and Davel Hill, eds., Revolutionizing Pedagogy: Education for Social Justice Within and Beyond Global Neoliberalism (New York: Palgrave Macmillan, 2010).

Madeley, John, A People's World (Manila: IBON Books, 2003)

Martinez, Elizabeth and Arnaldo Garcia "What is Neoliberalism: A Brief Definition for Activist," in CorpWatch, $<$ http://www.corpwatch.org/article.php?id=376>.

Marx, Karl The Economic and Philosophical Manuscripts, trans. by Gregor Benton, transcribed by Andy Blunden, in Marxist Internet Archive (1993),

https://www.marxists.org/archive/marx/works/1844/epm/1st.htm\#s 2>>.

von Mises, Ludwig, Liberalism, trans. by Ralph Raico (California: Cobden Press, 1985).

Parker, Ian, Revolution in Psychology: Alienation to Emancipation, (London: Pluto Press, 2007).

Peet, Richard, Unholy Trinity (Philippines: IBON Books, 2004).

Perelman, Michael, The Invention of Capitalism, (London: Duke University Press, 2000).

Schmidtz, David, and Jason Brennan, A Brief History of Liberty (London: Wiley and Blackwell, 2010).

Schweickart, David, After Capitalism (U.S.: Rowman \& Littlefield Publishers, Inc., 2002).

Sen, Amartya "Welfare, Preference, and Freedom" in Journal of Econometrics, 50 (1991).

(C) 2016 lan Raymond B. Pacquing

http://www.kritike.org/journal/issue 18/pacquing june2016.pdf

ISSN 1908-7330 


\section{NEOLIBERALISM}

Shah, Anup, "A Primer on Neoliberalism" in Global Issues (22 August 2010), $<$ http://www.globalissues.org/article/39/a-primer-on-neoliberalism>.

Singh, Kavaljit, Questioning Globalization (Manila: IBON Books, 2004).

Smith, Adam, Theory of Moral Sentiments, ed. by D.D. Raphael and A.L. Macfie, vol. I of The Glasgow Edition of the Works and Correspondence of Adam Smith (Indianapolis: Liberty Fund, 1982).

Stiglitz, Joseph, Globalization and Its Discontents, (New York: Allen Lane/Penguin Books, 2002)

Treanor, Paul, "Neoliberalism: Origins, Theory, and Definition," in Document Index (Paul Treanor Archive),

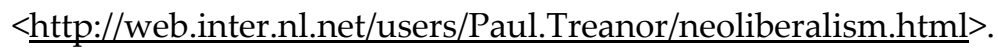

Wiggerhaus, Rolf, The Frankfurt School: Its History, Theories, and Political Significance, trans. by Michael Robertson (Cambridge: MIT Press, 1995).

Žižek, Slavoj, Living in the End Times (London: Verso, 2010). 